\title{
Effect of Planting Dates on Infestation of Thrips in Garlic Bulb Crop
}

\author{
Sujay Pandey ${ }^{1 *}$, M.K. Pathak ${ }^{1}$, B.K. Dubey ${ }^{1}$ and P.K. Gupta ${ }^{2}$ \\ ${ }^{1}$ National Horticultural Research and Development Foundation, Regional Research Station, \\ Vill.-Salaru, Post-Darar, Dist.- Karnal-132 001 (Haryana), India \\ ${ }^{2}$ National Horticultural Research and Development Foundation, Bagwani bhawan, Janakpuri, \\ New Delhi, India \\ *Corresponding author
}

\section{A B S T R A C T}

\begin{tabular}{|c|}
\hline Keywords \\
\hline $\begin{array}{l}\text { Garlic, Thrips, } \\
\text { Thrips tabaci, } \\
\text { Environmental } \\
\text { factors }\end{array}$ \\
\hline Article Info \\
\hline $\begin{array}{l}\text { Accepted: } \\
\text { 15 June } 2018 \\
\text { Available Online: } \\
10 \text { July } 2018\end{array}$ \\
\hline
\end{tabular}

The present study was conducted to observe the activity of thrips on garlic crop using variety Yamuna Safed-3 at Regional Research Station, NHRDF, Salaru, Karnal (Haryana) during three consecutive years i.e. Rabi, 2011-12, 2012-13 and 2013-14 seasons, which was based on a Randomized Block Design with six planting dates, i.e. October $1^{\text {st }}\left(\mathrm{D}_{1}\right)$, October $15^{\text {th }}\left(\mathrm{D}_{2}\right)$, November $1^{\text {st }}\left(\mathrm{D}_{3}\right)$, November $15^{\text {th }}\left(\mathrm{D}_{4}\right)$, December $1^{\text {st }}\left(\mathrm{D}_{5}\right)$ and December $15^{\text {th }}\left(\mathrm{D}_{6}\right)$. The bed size was kept as $3.6 \mathrm{~m} \times 1.8 \mathrm{~m}$ with 5 replications. The data on thrips population (nymphs/plant) were counted on 10 plants selected randomly in each replication at seven days interval. The result revealed that significantly lowest mean thrips population (4.71 nymphs/plant) were recorded in $1^{\text {st }}$ October planted crop, which was found at par with $15^{\text {th }}$ October planted crop (6.71 nymphs/plant) and $1^{\text {st }}$ November planted crop (7.74 nymphs/plant). Significantly highest mean thrips population (13.73 nymphs/plant) was recorded in $15^{\text {th }}$ December planted crop due to increase in temperature from 26.56 to $35.65^{\circ} \mathrm{C}$ during observational period. The significantly highest yield (113.39 $\mathrm{q} / \mathrm{ha}$ ) was recorded in $1^{\text {st }}$ October planted crop, which was found at par with $15^{\text {th }}$ October planted crop (111.21 q/ha) and $1^{\text {st }}$ November planted crop (105.92 q/ha).

\section{Introduction}

In India, garlic has been under cultivation for last 5000 years. The present production of garlic is about 16.17 lakh tons from an area about 2.80 lakh hectares (Indian Horticulture, 2017). Allium crops are attack by arthropod pests that can reduce crop yield and quality (Lorbeer et al., 2002).

Probably the most damaging pests worldwide are the insignificant looking thrips. They are found wherever alliums are grown, but are most severe in the warmer regions (Brewster, 1994).

Soni and Ellis (1990) listed the best known species of Thrips as Thrips tabaci. According to Kranz et al., (1977), the number of thrips on a crop can increase rapidly in dry weather and decrease rapidly after rain. According to Changela (1993), thrips caused up to 15.35 to 46.82 per cent yield loss of garlic. Considering the above problems field trials were conducted 
in three consecutive years during Rabi, 201112, 2012-13 and 2013-14 seasons on garlic variety Yamuna Safed-3 to assess the changes in number of thrips on garlic planted at different times of the growing season and to identify the time of peak incidence and decline at Regional Research Station, NHRDF, Salaru, Karnal (Haryana).

\section{Materials and Methods}

The field experiment was conducted at Regional Research Station, NHRDF, Karnal during Rabi, 2011-12, 2012-13 and 2013-14 seasons. The garlic cloves variety Yamuna Safed-3 was planted in a bed size of $3.6 \mathrm{~m} \mathrm{x}$ $1.8 \mathrm{~m}$ at $15 \mathrm{~cm} \times 10 \mathrm{~cm}$ spacing. Randomized Block Design with 5 replications was followed. The garlic cloves were planted on $1^{\text {st }}$ October $\left(D_{1}\right), 15^{\text {th }}$ October $\left(D_{2}\right), 1^{\text {st }}$ November $\left(D_{3}\right), 15^{\text {th }}$ November $\left(D_{4}\right), 1^{\text {st }}$ December $\left(D_{5}\right)$ and $15^{\text {th }}$ December $\left(\mathrm{D}_{6}\right)$. The data on thrips population (nymphs/plant) were counted visually with the help of hand lens on 10 plants selected randomly in each plot at seven days interval after appearance. The application of fungicides viz. mancozeb @ 2.5 g/lit. and carbendazim @2.0g/lit. were sprayed at 15 days interval alternatively in all dates of planted crop to protect the crop from diseases. All other agronomical practices were performed uniformly as per need in all the treatments. The crop was harvested after attaining the maturity. The data of three consecutive years i.e. Rabi, 2011-12, 2012-13 and 2013-14 were pooled analyzed statistically and are presented in Table 1.

\section{Results and Discussion}

\section{Rabi, 2011-12}

Data presented in Table 1 revealed that no significant differences for mean thrips population were recorded. Lowest mean thrips population (14.14 nymphs/plant) was recorded in $\mathrm{D}_{1}\left(1^{\text {st }}\right.$ October planted crop) and highest mean thrips population (15.28 nymphs/plant) was recorded in $\mathrm{D}_{6}\left(15^{\text {th }}\right.$ December planted crop). During the entire observational period highest thrips population (47.56 nymphs/plant) was recorded in $\mathrm{D}_{3}\left(1^{\text {st }}\right.$ November planted crop) on $13^{\text {th }}$ standard week with temperature ranged from 28.8 to $14.33^{\circ} \mathrm{C}$ and humidity from 61.50 to $47.50 \%$. Highest gross yield (116.06q/ha) was recorded in $\mathrm{D}_{2}$ ( $15^{\text {th }}$ October planted crop) followed by $\mathrm{D}_{1}$ (111.72q/ha), while lowest gross yield $(26.85 \mathrm{q} / \mathrm{ha})$ was recorded in $\mathrm{D}_{6}\left(15^{\text {th }}\right.$ December planted crop).

\section{Rabi, 2012-13}

Data presented in Table 2 revealed that thrips population did not appeared in $\mathrm{D}_{1}\left(1^{\text {st }}\right.$ October planted crop) and $\mathrm{D}_{2}\left(15^{\text {th }}\right.$ October planted crop) during entire observational period. Lowest mean thrips population (1.66 nymphs/plant) was recorded in $\mathrm{D}_{3}\left(1^{\text {st }}\right.$ November planted crop) and highest mean thrips population (10.84 nymphs/plant) was recorded in $\mathrm{D}_{6}\left(15^{\text {th }}\right.$ December planted crop). During the entire observational period highest thrips population (14.54 nymphs/plant) was recorded in $\mathrm{D}_{6}$ on $14^{\text {th }}$ standard week with temperature ranged from 32.25 to $14.17^{0} \mathrm{C}$ and humidity from 63.17 to $45.00 \%$. Significantly highest gross yield (105.55q/ha) was recorded in $\mathrm{D}_{1}\left(1^{\text {th }}\right.$ October planted crop) followed by $\mathrm{D}_{2} \quad(97.53 \mathrm{q} / \mathrm{ha})$, while lowest gross yield $(23.63 \mathrm{q} / \mathrm{ha})$ was recorded in $\mathrm{D}_{6}\left(15^{\text {th }}\right.$ December planted crop).

\section{Rabi, 2013-14}

Data presented in Table 3 revealed that thrips population did not appeared in $\mathrm{D}_{1}\left(1^{\text {st }}\right.$ October planted crop) and $\mathrm{D}_{2}\left(15^{\text {th }}\right.$ October planted crop) during entire observational period. Lowest mean thrips population (5.51 nymphs/plant) was recorded in $D_{3}\left(1^{\text {st }}\right.$ November planted crop) and highest mean thrips population (18.83 nymphs/plant) was recorded in $\mathrm{D}_{6}\left(15^{\text {th }}\right.$ December planted crop). 
During the entire observational period highest thrips population (27.78 nymphs/plant) was recorded in $\mathrm{D}_{6}\left(1^{\text {st }}\right.$ November planted crop) on $14^{\text {th }}$ standard week with temperature ranged from 32.32 to $15.2^{\circ} \mathrm{C}$ and humidity from 58.80 to $38.20 \%$. Significantly highest gross yield $(122.89 \mathrm{q} / \mathrm{ha})$ was recorded in $\mathrm{D}_{1}\left(1^{\text {st }}\right.$ October planted crop) which was at par with $\mathrm{D}_{2}$ $(120.03 \mathrm{q} / \mathrm{ha})$, while lowest gross yield $(75.65 \mathrm{q} / \mathrm{ha})$ was recorded in $\mathrm{D}_{6}\left(15^{\text {th }}\right.$ December planted crop).

Combined result during Rabi, 2011-12, 2012-13 \& 2013-14

As regard to pooled data pertaining to mean thrips population presented in Table 4 and
Figure 1 revealed that significantly lowest mean thrips population (4.71 nymphs/plant) were recorded in $1^{\text {st }}$ October $\left(D_{1}\right)$ planted crop, which was found at par with $15^{\text {th }}$ October $\left(\mathrm{D}_{2}\right)$ planted crop (6.71 nymphs/plant) and $1^{\text {st }}$ November $\left(D_{3}\right)$ planted crop $(7.74$ nymphs/plant). Significantly highest mean thrips population (13.73nymphs/plant) was recorded in $15^{\text {th }}$ December planted crop due to increase in temperature from 26.56 to 35.65 ${ }^{0} \mathrm{C}$ during observational period. The significantly highest yield (113.39 q/ha) was recorded in $1^{\text {st }}$ October planted crop, which was found at par with $15^{\text {th }}$ October planted crop $(111.21 \mathrm{q} / \mathrm{ha})$ and $1^{\text {st }}$ November planted crop (105.92 q/ha).

Fig.1 Effect of planting dates on infestation of thrips in garlic bulb crop at RRS, Karnal (Pooled data of 3 consecutive years during Rabi, 2011-12, 2012-13 and 2013-14

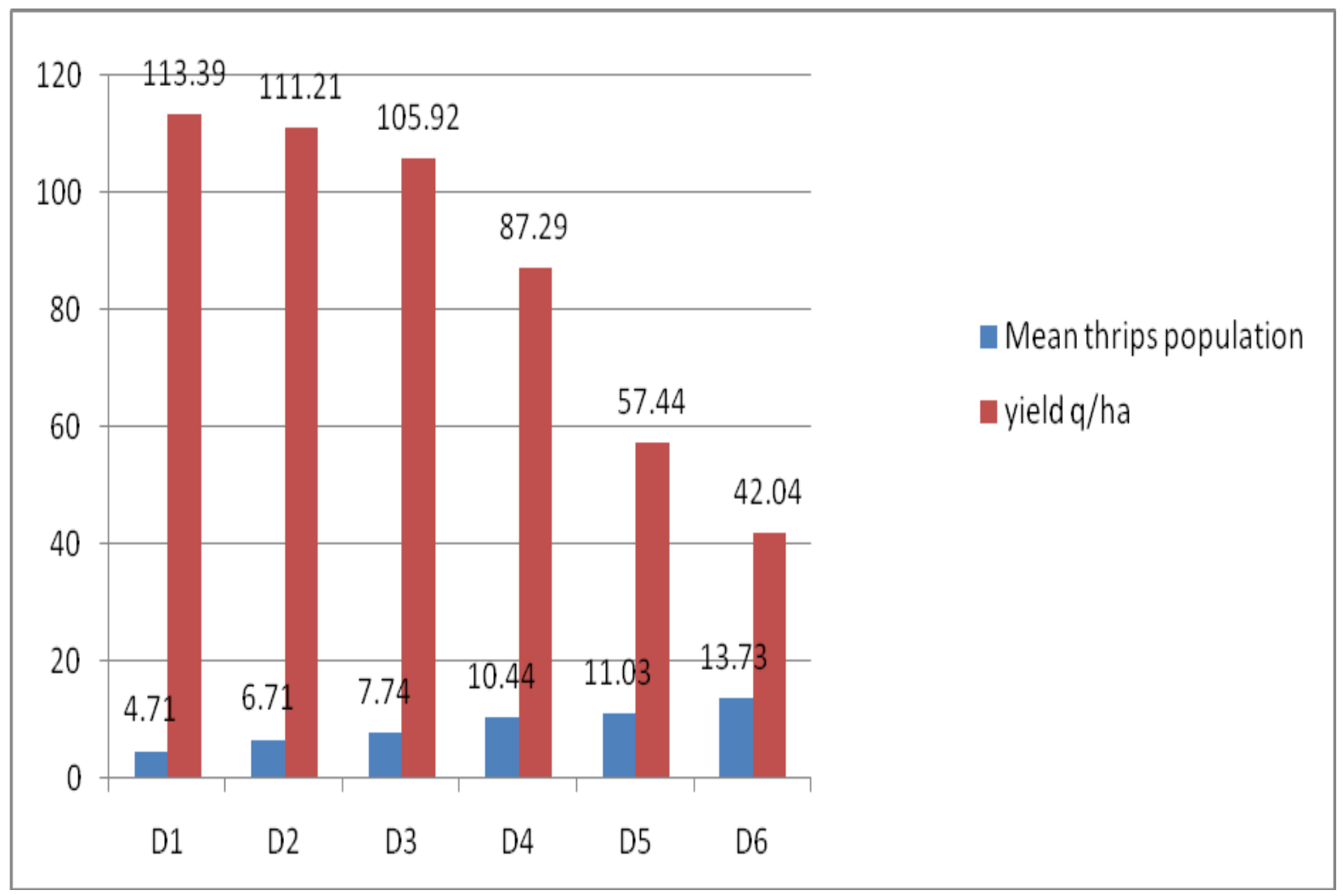


Table.1 Effect of planting dates on infestation of thrips in garlic at RRS, Karnal during Rabi, 2011-12

\begin{tabular}{|c|c|c|c|c|c|c|c|c|c|}
\hline Treatments & $\begin{array}{l}\text { Average } \\
\text { No. thrips } \\
\text { /plant at } \\
05 / 03 / 2012\end{array}$ & $\begin{array}{l}\text { Average } \\
\text { No. thrips } \\
\text { /plant at } \\
12 / 03 / 2012\end{array}$ & $\begin{array}{l}\text { Average } \\
\text { No. thrips } \\
\text { /plant at } \\
19 / 03 / 2012\end{array}$ & $\begin{array}{c}\text { Average } \\
\text { No. thrips } \\
\text { /plant at } \\
26 / 03 / 2012\end{array}$ & $\begin{array}{l}\text { Average } \\
\text { No. thrips } \\
\text { /plant at } \\
02 / 04 / 2012\end{array}$ & $\begin{array}{c}\text { Average } \\
\text { No. thrips } \\
\text { /plant at } \\
09 / 04 / 2012\end{array}$ & $\begin{array}{l}\text { Average } \\
\text { No. thrips } \\
\text { /plant at } \\
16 / 04 / 2012\end{array}$ & $\begin{array}{c}\text { Mean } \\
\text { thrips } \\
\text { population }\end{array}$ & $\begin{array}{l}\text { yield } \\
\text { q/ha }\end{array}$ \\
\hline $\mathbf{D}_{1}$ & 0.24 & 1.08 & 12.96 & 44.76 & 20.72 & 5.10 & 0.00 & 14.14 & 111.72 \\
\hline $\mathbf{D}_{2}$ & 0.36 & 1.16 & 13.12 & 45.00 & 24.00 & 4.68 & 0.00 & 20.12 & 116.06 \\
\hline $\mathbf{D}_{3}$ & 0.24 & 1.22 & 14.46 & 47.56 & 19.96 & 5.78 & 0.00 & 14.95 & 108.95 \\
\hline $\mathbf{D}_{4}$ & 0.34 & 0.94 & 13.50 & 47.12 & 19.62 & 9.00 & 9.38 & 14.29 & 97.65 \\
\hline $\mathbf{D}_{5}$ & 0.36 & 1.20 & 13.50 & 44.50 & 21.14 & 9.40 & 9.52 & 14.24 & 46.59 \\
\hline $\mathbf{D}_{6}$ & 0.20 & 1.32 & 14.22 & 43.88 & 20.96 & 15.76 & 10.66 & 15.28 & 26.85 \\
\hline S.Em \pm & 0.07 & 0.21 & 1.16 & 2.28 & 1.04 & 1.38 & 0.87 & 3.17 & 6.77 \\
\hline $\mathrm{CD}$ at $5 \%$ & NS & NS & NS & NS & 2.17 & 2.88 & 1.81 & NS & 14.12 \\
\hline CV \% & 39.67 & 28.67 & 13.42 & 7.94 & 7.79 & 26.25 & 27.84 & 32.29 & 12.64 \\
\hline
\end{tabular}

Table.2 Effect of planting dates on infestation of thrips in garlic at RRS, Karnal during Rabi, 2012-13

\begin{tabular}{|c|c|c|c|c|c|c|}
\hline Treatments & $\begin{array}{l}\text { Average No. thrips } \\
\text { /plant at } 4 / 03 / 2013\end{array}$ & $\begin{array}{l}\text { Average No. thrips } \\
\text { /plant at } \\
31 / 03 / 2013\end{array}$ & $\begin{array}{c}\text { Average No. } \\
\text { thrips } \\
\text { /plant at } \\
07 / 04 / 2013\end{array}$ & $\begin{array}{c}\text { Average No. } \\
\text { thrips } \\
\text { /plant at } \\
14 / 04 / 2013\end{array}$ & $\begin{array}{l}\text { Mean } \\
\text { thrips } \\
\text { population }\end{array}$ & $\begin{array}{l}\text { Yield } \\
\text { q/ha }\end{array}$ \\
\hline $\mathbf{D}_{1}$ & 0.00 & 0.00 & 0.00 & 0.00 & 0.00 & 105.55 \\
\hline $\mathbf{D}_{2}$ & 0.00 & 0.00 & 0.00 & 0.00 & 0.00 & 97.53 \\
\hline $\mathbf{D}_{3}$ & 6.64 & 0.00 & 0.00 & 0.00 & 1.66 & 95.68 \\
\hline $\mathbf{D}_{4}$ & 8.06 & 12.44 & 8.20 & 0.00 & 7.18 & 62.96 \\
\hline$D_{5}$ & 7.50 & 10.96 & 9.54 & 0.00 & 7.00 & 30.12 \\
\hline $\mathbf{D}_{6}$ & 7.50 & 9.64 & 14.54 & 11.66 & 10.84 & 23.63 \\
\hline S.Em \pm & 0.50 & 0.71 & 0.61 & 0.61 & 0.34 & 2.02 \\
\hline $\mathrm{CD}$ at $5 \%$ & 1.04 & 1.48 & 1.27 & 1.27 & 0.71 & 4.21 \\
\hline $\mathrm{CV} \%$ & 16.10 & 20.44 & 17.90 & 49.82 & 12.23 & 4.61 \\
\hline
\end{tabular}


Table.3 Effect of planting dates on infestation of thrips in garlic at RRS, Karnal during Rabi, 2013-14

\begin{tabular}{|c|r|r|r|r|r|r|r|r|}
\hline Treatments & $\begin{array}{c}\text { Average } \\
\text { No. thrips } \\
\text { /plant at } \\
20 / 03 / 2014\end{array}$ & $\begin{array}{c}\text { Average } \\
\text { No. thrips } \\
\text { /plant at } \\
27 / 03 / 2014\end{array}$ & $\begin{array}{c}\text { Average } \\
\text { No. thrips } \\
\text { /plant at } \\
\text { O3/04/2014 }\end{array}$ & $\begin{array}{c}\text { Average } \\
\text { No. thrips } \\
\text { /plant at } \\
10 / 4 / 2014\end{array}$ & $\begin{array}{c}\text { Average } \\
\text { No. thrips } \\
\text { /plant at } \\
174 / 2014\end{array}$ & $\begin{array}{c}\text { Average No. } \\
\text { thrips } \\
\text { /plant at } \\
24 / 4 / 2014\end{array}$ & $\begin{array}{c}\text { Mean thrips } \\
\text { population }\end{array}$ & yield q/ha \\
\hline$D_{1}$ & 0.00 & 0.00 & 0.00 & 0.00 & 0.00 & 0.00 & 0.00 & 122.89 \\
\hline$D_{2}$ & 0.00 & 0.00 & 0.00 & 0.00 & 0.00 & 0.00 & 0.00 & 120.03 \\
\hline$D_{3}$ & 6.10 & 11.98 & 14.96 & 0.00 & 0.00 & 0.00 & 5.51 & 113.14 \\
\hline$D_{4}$ & 4.56 & 10.46 & 15.92 & 18.28 & 19.34 & 0.00 & 11.43 & 101.26 \\
\hline$D_{\mathbf{5}}$ & 8.70 & 12.94 & 18.12 & 19.50 & 16.64 & 14.02 & 14.99 & 95.63 \\
\hline$D_{6}$ & 12.22 & 14.98 & 27.78 & 20.34 & 21.16 & 16.50 & 18.83 & 75.65 \\
\hline S.Em \pm & $\mathbf{0 . 7 1}$ & $\mathbf{0 . 6 4}$ & $\mathbf{2 . 0 3}$ & $\mathbf{1 . 5 8}$ & $\mathbf{0 . 5 0}$ & $\mathbf{0 . 8 2}$ & $\mathbf{0 . 5 4}$ & $\mathbf{1 . 7 3}$ \\
\hline CD at 5\% & $\mathbf{1 . 4 8}$ & $\mathbf{1 . 3 4}$ & $\mathbf{4 . 2 3}$ & $\mathbf{3 . 3 0}$ & $\mathbf{1 . 0 4}$ & $\mathbf{1 . 7 1}$ & $\mathbf{1 . 1 3}$ & $\mathbf{3 . 6 1}$ \\
\hline CV \% & $\mathbf{2 1 . 3 4}$ & $\mathbf{1 1 . 9 8}$ & $\mathbf{2 5 . 0 6}$ & $\mathbf{2 5 . 7 6}$ & $\mathbf{8 . 3 5}$ & $\mathbf{2 5 . 3 5}$ & $\mathbf{1 0 . 1 7}$ & $\mathbf{2 . 6 1}$ \\
\hline
\end{tabular}

Table.4 Effect of planting dates on infestation of thrips in garlic at RRS Karnal (Pooled Rabi, 2011-12, 2012-13 \& 2013-14)

\begin{tabular}{|c|r|r|r|r|r|r|}
\hline Treatments & $\begin{array}{c}\text { Average No. } \\
\text { thrips/plant at It } \\
\text { Week }\end{array}$ & $\begin{array}{c}\text { Average No. } \\
\text { thrips/plant at } \\
\text { II }^{\text {nd }} \text { Week }\end{array}$ & $\begin{array}{c}\text { Average No. } \\
\text { thrips/plant at } \\
\text { III }{ }^{\text {rd }} \text { Week }\end{array}$ & $\begin{array}{c}\text { Average No. } \\
\text { thrips/plant at } \\
\text { IV }^{\text {th }} \text { Week }\end{array}$ & $\begin{array}{c}\text { Mean thrips } \\
\text { population }\end{array}$ & yield q/ha \\
\hline $\mathbf{D}_{\mathbf{1}}$ & 0.08 & 0.36 & 6.91 & 1.70 & 4.71 & 113.39 \\
\hline $\mathbf{D}_{\mathbf{2}}$ & 0.12 & 0.39 & 8.00 & 1.56 & 6.71 & 111.21 \\
\hline $\mathbf{D}_{\mathbf{3}}$ & 4.33 & 4.40 & 11.64 & 1.93 & 7.74 & 105.92 \\
\hline $\mathbf{D}_{\mathbf{4}}$ & 4.32 & 7.95 & 14.58 & 9.09 & 10.44 & 87.29 \\
\hline $\mathbf{D}_{\mathbf{5}}$ & 5.52 & 8.37 & 16.27 & 9.63 & 11.03 & 57.44 \\
\hline $\mathbf{D}_{\mathbf{6}}$ & 6.64 & 8.65 & 21.09 & 15.92 & 13.73 & 42.04 \\
\hline S.Em \pm & $\mathbf{0 . 6 5}$ & $\mathbf{0 . 7 3}$ & $\mathbf{1 . 7 6}$ & $\mathbf{1 . 6 3}$ & $\mathbf{2 . 4 2}$ & $\mathbf{5 . 4 2}$ \\
\hline CD at 5\% & $\mathbf{1 . 4 5}$ & $\mathbf{1 . 6 2}$ & $\mathbf{3 . 9 2}$ & $\mathbf{3 . 6 2}$ & $\mathbf{5 . 3 8}$ & $\mathbf{1 2 . 0 8}$ \\
\hline
\end{tabular}

\section{Details of Treatments:}

$\mathrm{D}_{1}$ - Planting on $1^{\text {st }}$ October

$\mathrm{D}_{2}$ - Planting on $15^{\text {th }}$ October

$\mathrm{D}_{3}$ - Planting on $1^{\text {st }}$ November

$\mathrm{D}_{4^{-}}$Planting on $15^{\text {th }}$ November

$\mathrm{D}_{5^{-}}$Planting on $1^{\text {st }}$ December

$\mathrm{D}_{6}$ - Planting on $15^{\text {th }}$ December 
Different strategies have to be involved for keeping the pest in check and stabilizing the productivity of the cropping system. Date of planting is one of the crop habitat diversifications that are to be looked in to, to minimize the incidence of thrips on garlic crop so that its yield can be enhanced. However, there is no much information in literature to suggest the effect of date of planting on the activity of thrips on garlic except very few reports. The present study was conducted to observe the activity of thrips on garlic crop at Regional Research Station, NHRDF, Karnal (Haryana) during Rabi, 2011-12, 2012-13 \& 2013-14 aimed to enhance its bulb yield with minimum thrips intensity.

The thrips population showed a rising trend from its appearance during $1^{\text {st }}$ week of March to $3^{\text {rd }}$ week of April and a little declining trend thereafter due to maturity symptoms of crop as well as increase in temperature. The similar trend was also found by Sujay and Giraddi (2014) that late planted crop was liable for heavy infestation by insect pests. Time of planting of garlic influences the intensity of thrips. The results of this study are in agreement with Rahim, (1988) who showed that delay planting time reduced significantly the bulb yield. It may be due to that plant did not receive a long cool growing period which was essential for the development of the bulb (Swati et al., 2013).

In the light of combined data regarding thrips of garlic as affected by sowing dates as a pest control measure, it is concluded that early planting $\left(1^{\text {st }}\right.$ October or $15^{\text {th }}$ October) resulted in low incidence of thrips. Such low level of thrips population caused less crop injury which resulted in enhancing bulb yield of garlic. So, it is suggested that for early planting at Karnal region of Haryana the appropriate planting time can be October $1^{\text {st }}$ and/or October $15^{\text {th }}$.

\section{References}

Anonymous (2017): Indian Horticulture (Nov-Dec. 2017) Vol. 62(6): 2

Brewster J. L. (1994). Onions and other Vegetable Alliums. Horticulture Research International, Wellesbourne, CAB International. pp 236.

Changela, N.B. (1993). M.Sc. (Agri.) Thesis, Gujarat Agricultural University, Sardar Krushinagar, India pp. 83.

Kranz, S., Schmutterer, H., \& Koch, W. (1977). Diseases, Pests and Weeds in Tropical Crops, John Wiley and Sons, New York and Toronto. pp 666.

Lorbeer, J. W., Kuhar, T. P., \& Hoffmann, M. P. (2002). Monitoring and forecasting for Disease and Insect Attack in Onions and Allium crops within IPM strategies. In: Rabinowitch, H.D. and Currah, L. (Editors). Allium Crop Science: Recent Advances, pp 293-309,CABI, Wallingford, U.K.

Rahim M.A..(1988). Control of growth and bulbing of garlic (Allium sativum L.), Ph.D. Thesis, University of London.

Soni, S. K., \& Ellis, P. R. (1990). Insect Pests. In: Rabinowitch, H.D. and Brewster, J.L. (eds). Onions and Allied Crops, Vol. II. Agronomy, Biotic interactions, Pathology, and Crop Protection pp $213-271$. CRC press, Boca Raton, Florida, USA

Sujay, Y.H. and R.S. Giraddi. 2014. Investigation on the Effects of Planting Time and Plant Geometry on the Activity of Sucking Pests of Chilli Capsicum Annuum L. Global Journal of Science Frontier Research: D Agriculture and Veterinary, 14(4):1-10.

Swati, B.; Kirad, K. S. and Shrivastav, A. K. (2013). Effect of Planting Dates on Growth and Yield on Garlic (Allium sativum), International Journal of Horticulture, 2013, Vol.3, No.4 16-18 (doi: 0.5376/ijh.2013.03.0004).

\section{How to cite this article:}

Sujay Pandey, M.K. Pathak, B.K. Dubey and Gupta. P.K. 2018. Effect of Planting Dates on Infestation of Thrips in Garlic Bulb Crop. Int.J.Curr.Microbiol.App.Sci. 7(07): 1827-1832. doi: https://doi.org/10.20546/ijcmas.2018.707.216 